\title{
Reduced Bone Mineralization in Adolescent Survivors of Malignant Bone Tumors: Comparison of Quantitative Ultrasound and Dual-Energy X-Ray Absorptiometry
}

Cristina Azcona, M.D., Ph.D., Ellen Burghard, M.D., Elena Ruza, M.D., Juan Gimeno, M.D., and Luis Sierrasesúmaga M.D., Ph.D.

From the Department of Pediatrics, University Clinic, Faculty of Medicine, University of Navarra, Pamplona, Spain.

Fundación Echebano wholly funded the densitometer DBM 1200.

Address correspondence and reprint requests to Cristina Azcona, Department of Pediatrics, University Hospital, University of Navarra, Ave. Pío XII s/n, 31080 Pamplona, Spain.

E-mail: cazcona@unav.es.

\section{ABSTRACT}

Purpose: To assess bone mineralization in adolescents with bone tumors at remission using quantitative digital ultrasound (QUS) and dual-energy x-ray absorptiometry (DEXA), and to compare the bone mineralization values obtained by both methods.

Methods: Patients studied were 36 adolescents ( 21 boys, 15 girls) who had completed treatment of a bone tumor at the University Hospital of the University of Navarra (Pamplona, Spain). QUS was performed at the distal metaphysis of the proximal phalanxes of the last four fingers of the nondominant hand. A DBM Sonic 1200 Ultrasound densitometer was used. DEXA measurements were made at the lumbar spine (vertebrae L1-L4) using the Hologic QDR $4500 \mathrm{~W}$ device. Calcium and vitamin $\mathrm{D}$ daily intake and grade of physical activity were recorded.

Results: Mean age at bone mineralization determination was 19.11 years. Disease-free survival was 4.97 years. Decreased bone mineralization was observed by both methods. Bone mineralization absolute values measured by QUS and DEXA were significantly correlated. The sensitivity, specificity, diagnostic accuracy, and positive and negative predictive values of QUS for predicting osteopenia were $36.4 \%, 80.0 \%, 66.7 \%, 44.4 \%$, and $74.1 \%$, respectively. Daily vitamin D intake was below the recommended dietary allowances.

Conclusions: Adolescents in remission from bone tumors have low bone mineralization determined by DEXA or QUS.

Key Words: Adolescents; Bone mineralization; Bone tumors DEXA; Digital ultrasound. 


\section{INTRODUCTION}

Improvements in diagnostic methods and intensive treatment protocols in children and adolescents with malignancies have significantly increased survival rates, with approximately two thirds of these patients reaching adulthood (1). Therefore, the possible long-term consequences of treatment and the quality of life in these patients are becoming more important.

Many of the adverse effects of cancer treatment are well recognized, such as growth retardation, cardiomyopathy, and effects on fertility (2). Osteoporosis and fractures of long bones and spine have also been described $(3,4)$. In several studies, decreased bone mineralization has been demonstrated in long-term survivors of childhood acute lymphoblastic leukemia $(2,5,6)$ and in children with a malignancy at completion of their chemotherapy (7-9). However, recent studies are controversial with respect to bone mass status in this group of patients (10), and few studies have included patients with bone tumors $(11,12)$.

Skeletal manifestations in children and adolescents who have been treated for a malignancy are not unexpected, because they have been exposed to multiple agents known to impair the acquisition of bone mass (13). Corticosteroids and other antineoplastic treatments, such as methotrexate and radiotherapy, have been reported to interfere directly with the development of bone mass $(5-7,14,15)$. Nephrotoxic drugs such as ifosfamide and cisplatin, which are used for the treatment of bone tumors, may lead to abnormalities in renal calcium and vitamin D metabolism. Low levels of bone alkaline phosphatase throughout treatment for acute lymphoblastic leukemia have been described, suggesting impaired osteoblast differentiation $(8,16)$. Prolonged bedrest, poor nutrition, alterations in vitamin D metabolism, growth hormone deficiency, gonadal failure, and changes in insulin-like growth factors and their binding proteins might also influence bone mineralization in children with malignancies $(1,11,17)$.

In the elderly, bone mass is dependent on both the rate of bone loss and the peak bone mass attained during the second and third decades of life. Impaired accumulation of skeletal mass during childhood and adolescence might predispose survivors of childhood malignancies to osteopenia, osteoporosis, and pathologic fractures later in adulthood $(5,7)$.

Dual-energy x-ray absorptiometry (DEXA) is the most widely used technique for bone mass measurements. Compared with other methods to determine bone mineralization, such as single- and dual-photon absorptiometry and quantitative computed axial tomography, DEXA is especially suitable because of its high reproducibility (99\%), low precision errors (1\%), and low radiation doses (1-2 mRem) $(18,19)$. Unfortunately, DEXA cannot account for the large changes in body and skeletal size that occur during growth, limiting its use in longitudinal studies in children.

Several techniques to measure bone mineralization using ultrasound have been developed (20). This method measures the mean speed of sound through bone (Ad$\mathrm{SOS}, \mathrm{m} / \mathrm{s}$ ). The advantage of this method is that it can give information about the elastic quality of bone. This is an important quality since the risk of fractures depends not only on bone density but also on the elasticity of bone and its microarchitecture (21). Ultrasound has many other advantages compared with DEXA; there is less influence 
from both bone and body size, and it has a high reproducibility, with a low coefficient of variation (19). It can be performed in 3 minutes, its costs are low, it is portable, and there is no radiation involved, an aspect especially important in children. Soballa et al. have shown in osteoporotic women that the predictive value of low bone mineralization measured by quantitative digital ultrasound (QUS) in a peripheral bone is 0.93 for fracture in the spine or long bone (22).

Until now, there have been few bone mineralization data measured by DEXA in children with malignant bone tumors and no such data in these patients using QUS. The purpose of this study is to assess bone mineralization in children with bone tumors at remission using QUS and DEXA, and to compare the methods.

\section{METHODS}

\section{Patients}

We studied 36 adolescents (21 boys, 15 girls; 23 osteosarcomas and 13 Ewing sarcomas) of the 75 white patients who were treated and followed for a malignant bone tumor at the Department of Pediatrics of the University Hospital, University of Navarra (Pamplona, Spain) from 1984 to 2000. We included patients who were in remission, who were treated entirely in our hospital, and who did not have a disease that interfered with bone metabolism prior to diagnosis. Patients were treated according to the international cancer protocols (23-27) (Table 1). Each subject or the parents gave written informed consent prior to participation in the study. The study was approved by the Ethics Committee of the University Hospital.

\section{Methods}

Quantitative ultrasound was performed at the distal metaphysis of the proximal phalanxes of the last four fingers of the nondominant hand, obtaining the mean bone transmission speed of sound. A DBM Sonic 1200 ultrasound densitometer (IGEA, Italy) was used. Areal bone mineralization density DEXA measurements $\left(\mathrm{g} / \mathrm{cm}^{2}\right)$ were performed at the lumbar spine (vertebrae L1-L4) using an Hologic QDR4500 W (Hologic, Waltham, MA, U.S.A.). The coefficient of variation was $0.8 \%$ for DEXA and $0.7 \%$ for QUS. The results were expressed quantitatively as standard deviation scores (SDS) using previously published reference values $(19,28)$.

Height was determined to the nearest $1 \mathrm{~mm}$ using a Harpender stadiometer; weight was measured to the nearest $0.1 \mathrm{~kg}$ using a digital electronic instrument. Body mass index (BMI: weight $(\mathrm{kg}) /$ height $^{2}\left(\mathrm{~m}^{2}\right)$ ) was calculated. To calculate the SDS for height, weight, and BMI we used the reference values from Cole et al. (29).

Patients' daily intake of calcium and vitamin D was assessed using a questionnaire (30) adapted to our patients by the department's dietitians. The daily intake values of calcium and vitamin D were compared with the daily recommended allowances (31). The grade of physical exercise was assessed using a categorical scale modified from Kröger et al. (32). 


\section{Statistics}

All statistical and data recordings were done on a personal computer using SPSS version 10.0 (SPSS, Chicago, IL, U.S.A.). For all the variables studied, we determined mean, standard deviation, standard error, confidence interval, and sample size. Results are expressed as mean (confidence interval) or median (interquantile range).

A sample of 36 patients was enough to detect with a $\mathrm{P}$ value $<0.05$ a coefficient of correlation (r) of at least 0.33 . Coefficients of correlation below 0.33 were not of clinical interest. One sample Kolmogorov-Smirnov (Lilliefors) test was used to assess the normality of the variables. Paired $t$ tests or Mann-Whitney tests were used according to the normality of the variables. All $\mathrm{P}$ values were two-tailed, with a level of significance less than 0.05 . Pearson's correlation coefficients (r) were calculated to study the relationship between quantitative variables. Multivariate normality $(\mathrm{P}=0.382)$ (required for Pearson correlation) was assessed by the Small test (with a SPSS Macro) (23). A t test was used to test for mean SDS different from 0 . To compare the predictive power of QUS to detect osteopenia using DEXA as gold standard, the variable was dichotomized as osteopenia if the value was below or equal to -1 SDS and normal if higher than -1 SDS, according to the WHO classification. QUS sensitivity, specificity, positive and negative predictive values and diagnostic accuracy for detecting osteopenia were calculated using PEPI 4.0 (24).

\section{RESULTS}

Mean age at diagnosis was 14.27 years (range 12.66-15.89); at bone mineralization mean age was 19.41 years (range 17.81-21.02). Mean disease-free survival was 4.97 years (range 3.60-6.33). Mean height and weight-SDS at evaluation of bone mass were -0.08 (range $-0.50-0.33$ ) and 0.13 (range $-0.35-0.62$ ), respectively. Mean BMI was 0.42 (range $-0.08-0.90$ ) SDS. Weight, height, and BMI did not significantly differ from the mean value (29). All patients had developed normal full puberty. Linear growth had ceased in all patients. No patient had endocrine abnormalities. Location of primary tumors was femur $(42 \%)$, tibia (36\%), flat bones $(11 \%)$, humerus $(8 \%)$, and metacarpal (3\%). Histologic osteosarcoma types were as follows: 14 osteoblastic, 3 chondroblastic, 3 mixed, 2 telangiectatic, and 1 fibroblastic. Five patients had metastasis at diagnosis. All the patients with Ewing sarcoma received local radical radiotherapy and 15 patients with osteosarcoma received local intraoperative radiotherapy. Only two patients developed renal disease after therapy (loss of magnesium tubulopathy). Total cumulative doses of cytostatic agents are shown in Table 2.

Patients with bone tumors had significantly reduced lumbar areal bone mineral density at -0.58 (range -0.92 to -0.24$)$ SDS $(P=0.008)$ compared with references values (19). Bone mass assessed by QUS was -0.34 (range -0.85 to -0.17 ) SDS, lower though not significantly $(\mathrm{P}=0.18)$ compared to reference values $(28)$. The absolute values of bone mineralization determined by QUS (Ad-SOS; m/s) and DEXA $\left(\mathrm{g} / \mathrm{cm}^{2}\right)$ were significantly correlated $(\mathrm{n}=36, \mathrm{r}=0.44 ; \mathrm{P}=0.008)$.

There were no significant differences in BMI, height, and weight related to sex or type of tumor (Table 3). No differences in bone mineralization were found related to the type 
of tumor or type of treatment (Table 4). However, there were significant differences in DEXA absolute values $\left(\mathrm{g} / \mathrm{cm}^{2}\right)$ and QUS-SDS values with respect to sex.

Sensitivity of QUS for predicting osteopenia was 36.4\% (range 12.8\%-66.4\%) and specificity was $80.0 \%$ (range $61.1 \%-92.3 \%$ ). Ad-SOS positive predictive value was $44.4 \%$ (range $20.9 \%-70.8 \%$ ), and Ad-SOS negative predictive value was $74.1 \%$ (range $63.7 \%$ to $82.3 \%$ ). QUS diagnostic accuracy was $66.7 \%$ (range $50.2 \%$ to $80.5 \%$ ).

The mean daily intake of vitamin $\mathrm{D}$, at $0.89 \mathrm{mcg}$ (range $0.70-1.70$ ) was significantly (P $<0.001$ ) below the recommended dietary allowances (31). Physical activity seemed to be low as well, since $80 \%$ of patients performed physical activity less than 2 hours per week. None of the patients had bone fractures. No significant correlation between daily intake of calcium and vitamin $\mathrm{D}$, physical activity, and bone mineralization was found.

\section{DISCUSSION}

The patients studied had lower bone mineralization than the reference population determined by both DEXA and QUS. It is valuable to evaluate bone mass in children and adolescents in or at remission from cancer because it has been speculated that decreased bone mineralization in youth means a risk for developing osteoporosis later in adulthood. A decrease of $1 \mathrm{SD}$ in bone mineralization has been shown to increase the risk for osteoporotic fractures by about $40 \%$ to $50 \%$ in the perimenopausal population (25). If decreased bone mineralization is detected early, factors that might contribute to the low value should be recognized and if possible treated. Few patients with bone tumors have been included in previous studies of bone mass after childhood cancer $(11,12)$.

The cause of this decreased bone mass in children with cancer is probably multifactorial, as described in the introduction. We did not investigate all factors involved, but we assessed nutritional factors and physical activity in relation with bone mineralization. In this study, the growth hormone status of our patients was not directly assessed, but their normal height and lack of clinical signs or symptoms of growth hormone deficiency make it unlikely that this factor contributes to their low bone mass. They also had developed full and normal puberty, so sex hormone abnormalities did not seem to be involved in their low bone mass.

Some of the cancer therapies used to treat these types of tumors seem to impair skeletal mass, including chemotherapeutic agents such as methotrexate, ifosfamide, and doxorubicin $(33,34)$ and local radiotherapy. Methotrexate inhibits DNA synthesis, leading to a block in pyrimidine and purine synthesis. Administration of oral methotrexate has been previously associated with osteoporosis $(3,4)$. Patients with osteosarcoma receive high doses of methotrexate, a drug that interferes with acquisition of trabecular bone (35), as do other drugs, such as ifosfamide and bleomycin. Ifosfamide and cisplatin can also affect bone metabolism and therefore lead to osteopenia (34).

The intake of calcium and vitamin $\mathrm{D}$ was below the recommended dietary allowances in our patients. Their physical activity was low as well due to the disabilities children develop after surgery. Some factors that have a negative influence on bone mass in 
children with bone tumors, such as the disease itself, its treatment, and bedrest, are difficult to modify. However, the intake of sufficient amounts of calcium and vitamin D can be achieved. It would be important to perform studies to see whether an adequate intake of calcium and vitamin D would decrease the risk of osteoporosis and fractures later in adulthood $(5,7)$. Children with bone tumors have physical barriers to exercise, but patients in remission should be encouraged to participate in physical activities because even moderate increases in physical activity are associated with moderate but important increases in skeletal mass (36).

The two methods we used both have their advantages and disadvantages. DEXA is very precise, but radiation is involved and patients must lie still for 10 to 20 minutes. In children with bone tumors, radiation and immobilization can cause problems. With QUS, no radiation is involved and children cooperate well. Other important advantages are that it is easy, portable, and inexpensive. Alterations in body composition may interfere with the transmission of sound, which accounts for the relatively low mean speed of sound in obese people and the relatively high mean speed of sound in thin people. This illustrates a disadvantage of QUS in obese or thin patients: the measurements can be, respectively, under- or overestimated. We do not know if this was the case in our patients because we did not directly assess body composition, although the patients' weight and BMI did not significantly differ from the control population. Therefore, we do not know if fat mass altered the bone mineralization values that were determined using QUS.

The way that body composition affects bone mass in children is controversial. Although it has been previously described that overweight children are skeletally advanced (37), recent studies have observed that a high proportion of children with distal forearm fractures are overweight and have lower bone mass and bone area density (38-46). Since physical activity is strongly osteogenic during growth, diminished participation in weight-bearing exercise by overweight children could have an adverse effect on bone development. However, other authors believe that bone mass in overweight children is expected to be high because of the higher intake of food (calcium and vitamin D) and the larger weight they must bear, which has a positive influence on bone mass $(32,47)$. In our patients both lack of exercise and low intake of food, both during therapy and while recovering from surgery, may have had an adverse impact on their bone mass.

The predictive power of ultrasound measurements by means of broadband ultrasound attenuation with regard to femoral and spinal fracture risk has been demonstrated several times in osteoporotic women $(22,39-41)$. However, most of the studies performed to predict fractures using QUS have been done using ultrasound in the calcaneus (39-41). QUS does not show good diagnostic accuracy for detecting osteopenia in children with cancer, using DEXA as the gold standard.

In conclusion, children in remission from a bone tumor have a lower bone mass than the reference population. This was observed by both methods we used. QUS does not seem to be a good technique for detecting osteopenia in this group of children. A follow-up determination of bone mass should be carried out to identify patients who require specific therapeutic interventions to prevent any further decrease in skeletal mass. More validation studies are needed to use QUS as a technique to detect osteopenia in children. Nutritional follow-up is also necessary to identify patients who may benefit from calcium and vitamin D supplements. 


\section{ACKNOWLEDGMENTS}

The authors thank the children and their families who participated in this study and the nurses and ward technicians for their expert assistance. The authors thank dietitians Leyre Alonso and María Portas for their estimable help in the nutritional assessment.

\section{REFERENCES}

1. Arikoski $\mathrm{P}$, Kröger $\mathrm{H}$, Riikonen $\mathrm{P}$, et al. Disturbance in bone turnover in children with a malignancy at completion of chemotherapy. Med Pediatr Oncol 1999; 33:455-61.

2. D'angelo P, Conter V, Di Chiara G, et al. Severe osteoporosis and multiple vertebral collapses in a child during treatment for B-ALL. Acta Haematol 1993; $89: 38-42$.

3. Ragab AH, Frech RS, Vietti TJ. Osteoporotic fractures secondary to methotrexate therapy of acute leukemia in remission. Cancer 1970;25:580-5.

4. Schwartz AM, Leonidas JC. Methotrexate osteopathy. Skeletal Radiol 1984;11: 13-6.

5. Hoorweg-Nijman JJG, Kardos G, Roos JC, et al. Bone mineral density in young adult survivors of childhood lymphoblastic leukaemia. In: Schonau E, Matkovic V, eds. Paediatric osteology, prevention of osteoporosis: a paediatric task? 1998:143-9.

6. Arikoski P, Komulainen J, Voutiliainen R, et al. Reduced bone mineral density in long-term survivors of childhood acute lymphoblastic leukaemia. J Pediatr Hematol Onc 1998;20:234-40.

7. Nysom K, Holm K, Michaelsen KF, et al. Bone mass after treatment for acute lymphoblastic leukemia in childhood. J Clin Oncol 1998;16:3752-60.

8. Arikoski P, Komulainen J, Riikonen $\mathrm{P}$, et al. Reduced bone density at completion of chemotherapy for a malignancy. Arch Dis Child 1999;80:143-8.

9. Nysom K, Holm K, Michaelsen KF, et al. Bone mass after treatment of malignant lymphoma in childhood. Med Pediatr Oncol 2001;37:518-24.

10. Crofton PM, Ahmed SF, Wade JC, et al. Effects of intensive chemotherapy on bone and collagen turnover and the growth hormone axis in children with acute lymphoblastic leukemia. J Clin Endocrinol Metab 1998;83:3121-9.

11. Vassilopoulous-Sellin, Brosnan P, Delpassand A, et al. Osteopenia in young adult survivors of childhood cancer. Med Pediatr Oncol 1999;32;272-8.

12. Aisenberg J, Hsieh K, Kalaitzoglou G, et al. Bone mineral density in young adult survivors of childhood cancer. J Pediatr Hematol Oncol 1998;20:241-5.

13. Nysom K, Holm $\mathrm{K}$, Hertz $\mathrm{H}$, et al. Bone mass after treatment for acute lymphoblastic leukemia in childhood. J Clin Oncol 2001;19:2970-1.

14. Henderson R, Madsen C, Davis C, et al. Bone density in survivors of childhood malignancies. J Pediatr Hematol Oncol 1996;18:367-71.

15. Halton J, Atkinson S, Franer L, et al. Altered mineral metabolism and bone mass in children during treatment for acute lymphoblastic leukaemia. J Bone Miner Res 1996;11:1774-83.

16. Crofton PM, Ahmed SF, Wade JC, et al. Bone turnover and growth during and after continuing chemotherapy in children with acute lymphoblastic leukemia. Pediatr Res 2000;48:490-6. 
17. Atkinson SA, Halton JM, Bradley C, et al. Bone and mineral abnormalities in childhood acute lymphoblastic leukemia: influence of disease, drugs and nutrition. Int J Cancer (suppl) 1998;1135-9.

18. Glastre C, Braillon P, David L. Measurement of bone mineral content at the lumbar spine by dual-energy X-ray absorptiometry in normal children in correlation with growth parameters J Clin Endocrinol Metab 1990;70:1330-3.

19. Del Rio L, Carrascosa A, Pons F. Bone mineral density of the lumbar spine in Caucasian Mediterranean Spanish children and adolescents; changes related to age, sex and puberty. Pediatr Res 1994;35:362-6.

20. Gilsanz V. Bone density in children: a review of the available techniques and indications. Eur J Radiol 1998;26:177-82.

21. Gluer $\mathrm{CC}, \mathrm{Wu} \mathrm{CY}$, Jergus $\mathrm{M}$, et al. Three quantitative ultrasound parameters reflect bone structure. Calcif Tissue Int 1994;55:46-52.

22. Soballa T, Wuster C, Schlege 1J, et al. Ultrasound transmission speed and ultrasound bone profile score of the phalanges in normal women with osteoporosis. Horm Metab Res 1998;30:536-41.

23. DeCarlo LT. On the meaning and use of kurtosis. Psychol Methods 1997;2:292307.

24. Abramson JH, Gahlinger PM. Computer programs for epidemiologists: PEPI Version 4.0. Sagebrush Press, Salt Lake City, UT, U.S.A., 2001.

25. Arikoski P, Komulainen J, Riikonen P, et al. Skeletal problems in children with malignancies. In: Schonau E, Matkovic V, eds. Paediatric osteology, prevention of osteoporosis: a paediatric task? 1998:137-41.

26. Meyers PA, Heller G, Healey J, et al. Chemotherapy for nonmetastatic osteogenic sarcoma: the Memorial Sloan-Kettering experience. J Clin Oncol $1992 ; 10: 5-15$.

27. Rosen G, Juergens H, Caparros B, et al. Combination chemotherapy (T-6) in the multidisciplinary treatment of Ewing's sarcoma. Natl Cancer Inst Monogr 1981; 56:289-99.

28. Gimeno J, Azcona C, Modesto C, et al. Mineralización ósea por ultrasonidos: Curvas de normalidad en la población infanto-juvenil navarra. Anales Españoles de Pediatría 2001;54:540-6.

29. Cole TJ, Freeman JV, Preece MA. British 1990 growth reference centiles for weight, height, body mass index and head circumference fitted by maximum penalized likelihood. Stat Med 1998;17:407-29.

30. Friedenreich CM, Slimani N, Riboli E. Measurement of past diet: review of previous and proposed methods. Epidemiol Rev 1992;14:177-96.

31. Varela G. Ingestas recomendadas de energía y nutrientes para la población española. Departamento de Bromatología y Nutrición. Universidad Complutense, Madrid, 1994.

32. Kröger H, Kotaniemi A, Kröger L, et al. Development of bone mass and bone density at the spine and femoral neck: a prospective study of 65 children and adolescents. Bone Miner 1993;23:171-82.

33. Nesbit M, Krivit W, Heyn R, et al. Acute and chronic effects of methotrexate on hepatic, pulmonary, and skeletal systems. Cancer 1976;37(suppl):1048-54.

34. Schepper de J, Hachimi-Idrissi S, Louis O, et al. Bone metabolism and mineralisation after cytotoxic chemotherapy including ifosfamide. Arch Dis Child 1994;71:346-8. 
35. Gnudi S, Butturini, Ripamonti C, et al. The effects of methotrexate on bone: a densitometric study conducted on 59 patients with MTX administered at different doses. Ital J Orthop Traumatol 1988;14:227-31.

36. Slemenda CW, Miller JL, Hui SL, et al. Role of physical activity in the development of skeletal mass in children. J Bone Miner Res 1991;6:1227-33.

37. Klein KO, Larmore KA, de Lancey E, et al. Effect of obesity on estradiol level, and its relationship to leptin, bone maturation, and bone mineral density in children. J Clin Endocrinol Metab 1998;83:3469-75.

38. Goulding A, Cannan R, Williams S, et al. Bone mineral density in girls with forearm fractures. J Bone Min Res 1998;13:143-8.

39. Hans D, Dargen-Molina P, Chott AM, et al. Ultrasonic heel measurements to predict hip fractures in elderley women: the EPIDOS Prospective Study. Lancet 1996;348:511-4.

40. Bauer DC, Gluer CC, Cauley JA, et al. Broadband ultrasonic attenuation predicts fractures strongly and independently of densitometry in older women. Arch Intern Med 1997; 157:629-34.

41. Cardenas JL, Revilla M, Hernandez ER, et al. Comparison of three bone densitometry methods in osteoporotic women. Calcif Tissue Int 1997;61:358-61.

42. Zamboni G, Soffiati M, Giavarina D, et al. Mineral metabolism in obese children. Acta Paediat Scand 1988;77:741-6.

43. McCormick DP, Ponder SW, Fawcett D, et al. Spinal bone mineral density in 335 normal and obese children and adolescents: evidence for ethnic and sex differences. J Bone Min Res 1991;6:507-13.

44. De Schepper J, Van de Broeck M, Jonckheer MH. Study of lumbar spine bone mineral density in obese children. Acta Paediatr 1995;84:313-5.

45. Goulding A, Taylor RW, Jones IE, et al. Overweight and obese children have low bone mass and area for their weight. Int J Obes Relat Metab Disord 2000; 24:627-32.

46. Goulding A, Jones IE, Taylor RW, et al. More broken bones: a 4-year double cohort study of young girls with and without distal forearm fractures. J Bone Miner Res 2000;15:2011-8.

47. Mølgaard C, Thomsen B, Fleisher Michaelsen K. Influence of weight, age and puberty on bone size and bone mineral content in healthy children and adolescents. Acta Paediatr 1998;87:494-9. 
TABLE 1. Chemotherapy regimens

Osteosarcoma

Before surgery

\begin{tabular}{lcccc}
\hline Cytostatic & Dose & Days, $n$ & Frequency & Cycles, $n$ \\
\hline Cisplatin & $40 \mathrm{mg} / \mathrm{m}^{2}$ IA & 3 & every 3 weeks & 3 \\
Doxorubucin & $30 \mathrm{mg} / \mathrm{m}^{2}$ IV & 3 & every 3 weeks & 2 \\
\hline
\end{tabular}

Postsurgery (2 weeks)

Cytostatic

Dose

Days

Frequency (weeks)

Methotrexate

$8 \mathrm{~g} / \mathrm{m}^{2} \mathrm{IV}$

$60 \mathrm{mg} / \mathrm{m}^{2}$ IV

$30 \mathrm{mg} / \mathrm{m}^{2}$ IV

$15 \mathrm{mg} / \mathrm{m}^{2}$ IV

$0,6 \mathrm{mg} / \mathrm{m}^{2}$ IV

$600 \mathrm{mg} / \mathrm{m}^{2}$ IV

$1 \mathrm{~g} / \mathrm{m}^{2} \mathrm{IV}$

$1.5 \mathrm{mg} / \mathrm{m}^{2}$ IV

1,2 and 3

1,2 and 3

1,2 , and 3

1,2 and 3

1,2 and 3

or Ifosfamide

$1.5 \mathrm{mg} / \mathrm{m}^{2} \mathrm{IV} \quad 1$

Ewing sarcoma

Cycle

Cytostatic

Dose

Days

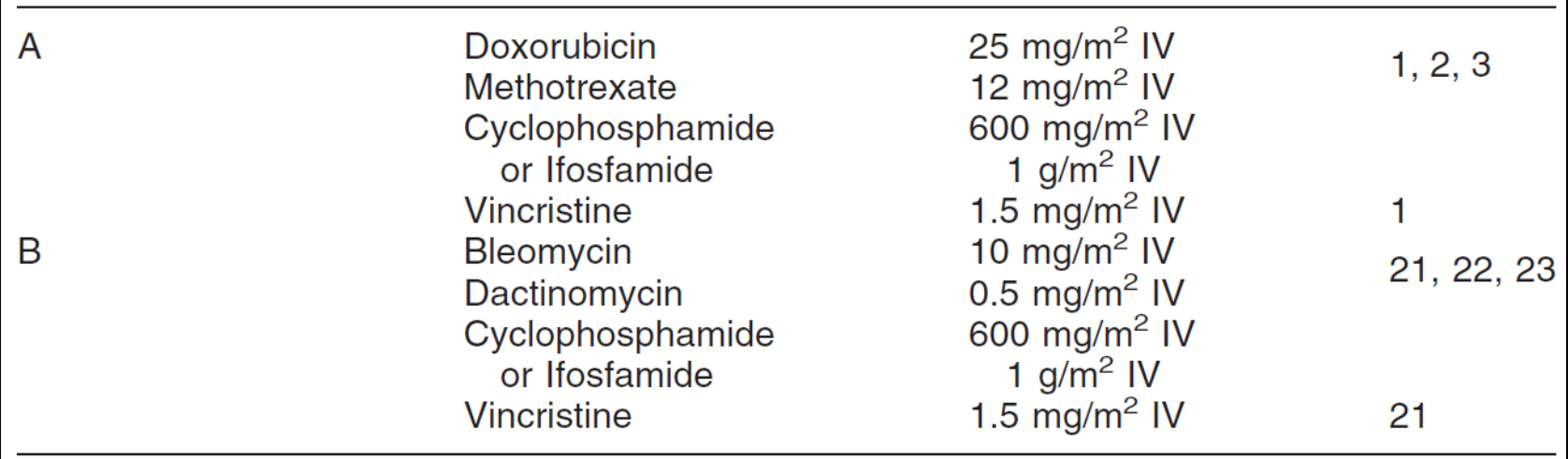

Cycle $A$ and $B$ are alternate every 21 days for 9-10 months.

IA, intrarterial; IV, intravenous. 
Table 2. Total cumulative doses of cytostatic agents in patients with osteosarcoma and Ewing sarcoma, comparison between both protocols.

\begin{tabular}{|l|c|c|c|}
\hline & Osteosarcoma & Ewing sarcoma & P value \\
\hline Methotrexate $\left(\mathrm{g} / \mathrm{m}^{2}\right)$ & $65.55(37.13 ; 84.50)$ & $0.23(0.21 ; 0.28)$ & $<0.001$ \\
\hline Cyclophosphamide $\left(\mathrm{g} / \mathrm{m}^{2}\right)$ & $4.25(2.02 ; 6.03)$ & $17.73(13.83 ; 21.78)$ & $<0.001$ \\
\hline Ifosfamide $\left(\mathrm{g} / \mathrm{m}^{2}\right)$ & $17.94(10.87 ; 32.02)$ & $35.01(6.78 ; 52.50)$ & $\mathrm{NS}$ \\
\hline Doxorubicin $\left(\mathrm{mg} / \mathrm{m}^{2}\right)$ & $428.54(121.58)$ & $470.39(178.42)$ & $\mathrm{NS}$ \\
\hline Actinomicin $\mathrm{D}\left(\mathrm{mg}^{2} \mathrm{~m}^{2}\right)$ & $4.30(3.25 ; 6.50)$ & $9.67(3.70)$ & $<0.001$ \\
\hline Bleomycin $\left(\mathrm{mg} / \mathrm{m}^{2}\right)$ & $95.87(44.59)$ & $170.80(63.16)$ & $<0.001$ \\
\hline Vincristine $\left(\mathrm{mg} / \mathrm{m}^{2}\right)$ & $6.31(3.85 ; 9.27)$ & $24.05(17.93 ; 35.79)$ & $<0.001$ \\
\hline Cisplatin $\left(\mathrm{mg} / \mathrm{m}^{2}\right)$ & $465.98(146.11)$ & - & \\
\hline NS, not stated. & & & \\
\hline
\end{tabular}

\begin{tabular}{|l|c|c|c|c|c|c|}
\hline \multicolumn{7}{|c|}{ Table 3. Clinical characteristics of the study population (n=36) } \\
\hline & $\begin{array}{c}\text { Osteosarcoma } \\
(\mathbf{n}=\mathbf{2 3})\end{array}$ & $\begin{array}{c}\text { Ewing } \\
\text { sarcoma } \\
(\mathbf{n}=\mathbf{1 3})\end{array}$ & $\mathbf{P}$ & $\begin{array}{c}\text { Females } \\
(\mathbf{n}=\mathbf{2 1})\end{array}$ & $\begin{array}{c}\text { Males } \\
(\mathbf{n}=\mathbf{1 5})\end{array}$ & $\boldsymbol{P}$ \\
\hline $\begin{array}{l}\text { Age at } \\
\text { diagnosis } \\
\text { (years) }\end{array}$ & $\begin{array}{c}13.73 \\
(11.63 ; 15.84)\end{array}$ & $\begin{array}{c}15.23 \\
(12.42 ; 18.03)\end{array}$ & 0.828 & $\begin{array}{c}13.58 \\
(10.81 ; 16.36)\end{array}$ & $\begin{array}{c}14.77 \\
(12.65 ; 16.88)\end{array}$ & 0.583 \\
\hline $\begin{array}{l}\text { Age at study } \\
\text { (years) }\end{array}$ & $\begin{array}{c}19.63 \\
(17.37 ; 21.89)\end{array}$ & $\begin{array}{c}19.03 \\
(16.68 ; 21.37)\end{array}$ & 0.252 & $\begin{array}{c}20.24 \\
(17.77 ; 22.71)\end{array}$ & $\begin{array}{c}18.83 \\
(16.58 ; 21.08)\end{array}$ & 0.658 \\
\hline $\begin{array}{l}\text { Height at } \\
\text { study (SDS) }\end{array}$ & $\begin{array}{c}-0.04 \\
(-0.46 ; 0.53)\end{array}$ & $\begin{array}{c}-0.31 \\
(-1.17 ; 0.53)\end{array}$ & 0.798 & $\begin{array}{c}0.25 \\
(-0.33 ; 0.82)\end{array}$ & $\begin{array}{c}-0.33 \\
(-0.94 ; 0.28)\end{array}$ & 0.246 \\
\hline $\begin{array}{l}\text { Weight at } \\
\text { study (SDS) }\end{array}$ & $\begin{array}{c}0.04 \\
(-0.55 ; 0.62)\end{array}$ & $\begin{array}{c}0.30 \\
(-0.67 ; 1.28)\end{array}$ & 0.795 & $\begin{array}{c}0.28 \\
(-0.48 ; 1.03)\end{array}$ & $\begin{array}{c}0.03 \\
(-0.66 ; 0.72)\end{array}$ & 0.432 \\
\hline $\begin{array}{l}\text { Body mass } \\
\text { index (SDS) }\end{array}$ & $\begin{array}{c}0.31 \\
(0.28 ; 0.91)\end{array}$ & $\begin{array}{c}0.61 \\
(-0.47 ; 1.69)\end{array}$ & 0.469 & $\begin{array}{c}0.40 \\
(-0.48 ; 1.29)\end{array}$ & $\begin{array}{c}0.44 \\
(-0.26 ; 1.13)\end{array}$ & 0.837 \\
\hline
\end{tabular}


Table 4. Comparison of body mass by both methods in both group of patients and by sex

\begin{tabular}{|c|c|c|c|c|c|c|}
\hline $\begin{array}{l}\text { Body mass } \\
\text { index }\end{array}$ & $\begin{array}{c}\text { Osteosarcoma } \\
(\mathbf{n}=23)\end{array}$ & $\begin{array}{c}\text { Ewing Sarcoma } \\
(\mathrm{n}=13)\end{array}$ & $\boldsymbol{P}$ & $\begin{array}{c}\text { Females } \\
(n=21)\end{array}$ & $\begin{array}{c}\text { Males } \\
(n=15)\end{array}$ & $\boldsymbol{P}$ \\
\hline $\begin{array}{l}\text { QUS } \\
(\text { Ad-SOS) } \\
(\mathrm{m} / \mathrm{s})\end{array}$ & $\begin{array}{c}2044.78 \\
(2011.03 ; \\
2078.53)\end{array}$ & $\begin{array}{c}2048.77 \\
(1994.45 \\
2103.09)\end{array}$ & 0.592 & $\begin{array}{c}2037.00 \\
(1984.32 ; \\
2089.68) \\
\end{array}$ & $\begin{array}{c}2052.81 \\
(2020.26 \\
2085.36)\end{array}$ & 0.387 \\
\hline $\begin{array}{l}\text { QUS } \\
\text { (Ad-SOS) } \\
(\mathrm{SDS}) \\
\end{array}$ & $\begin{array}{c}-0.26 \\
(0.83 ; 0.32)\end{array}$ & $\begin{array}{c}-0.48 \\
(-1.60 ; 0.64)\end{array}$ & 0.362 & $\begin{array}{c}-0.90 \\
(-1.98 ; 0.19)\end{array}$ & $\begin{array}{c}0.06 \\
(-0.39 ; 0.50)\end{array}$ & 0.033 \\
\hline $\begin{array}{l}\text { DEXA } \\
\left(\mathrm{g} / \mathrm{cm}^{2}\right)\end{array}$ & $\begin{array}{c}0.93 \\
(0.87 ; 0.99)\end{array}$ & $\begin{array}{c}0.97 \\
(0.89 ; 1.05)\end{array}$ & 0.685 & $\begin{array}{c}0.98 \\
(0.93 ; 1.03)\end{array}$ & $\begin{array}{c}0.92 \\
(0.84 ; 0.99)\end{array}$ & 0.009 \\
\hline $\begin{array}{l}\text { DEXA } \\
\text { (SDS) }\end{array}$ & $\begin{array}{c}-0.59 \\
(-1.08 ;-0.11)\end{array}$ & $\begin{array}{c}-0.57 \\
(-1.07 ;-0.08)\end{array}$ & 0.527 & $\begin{array}{c}-0.18 \\
(-0.75 ; 0.39)\end{array}$ & $\left(\begin{array}{c}-0.87 \\
(-1.29 ;-0.46)\end{array}\right.$ & 0.891 \\
\hline
\end{tabular}

